\title{
Effect of B-success herbal supplement on the accessory sex organs of male albino rats
}

\author{
Obi EJEATULUCHUKWU ${ }^{1 *}$, Agbasi Patrick UGOCHUKWU ${ }^{2}$ and \\ Orish Ebere ORISAKWE ${ }^{3}$ \\ ${ }^{1}$ Toxicology Unit, Department of Pharmacology, College of Health Sciences, Nnamdi Azikiwe University, \\ Nnewi Campus, Anambra State, Nigeria. \\ ${ }^{2}$ Federal University of Technology, Owerri, Imo State, Nigeria. \\ ${ }^{3}$ Toxicology Unit, Faculty of Pharmacy,University of Port Harcourt, Rivers State, Nigeria. \\ *Corresponding author; Email: ejeatuluobi@yahoo.com
}

\begin{abstract}
This work investigated the effect of B-success herbal supplement on the accessory sex organs of male albino rats. Twenty weights matched male albino rats were divided into four groups of five rats and were given $0.00,315,630,945 \mathrm{mg} / \mathrm{kg}$ of the herbal product orally for 90 days. Animals had access to deionized water and were fed ad libitum with rat chow for 90 days. The feed and fluid consumption of the animals were measured on daily basis while the body weight was measured weekly. Animals were anaesthetized after 90 days, bled sacrificed, epididymis, seminal vesicle and prostate were excised and weighed, protein, DNA. The epididymal tissues were also used for the determination of acid phosphatase and alkaline phosphatase. The result shows that there was significant $(\mathrm{P} \leq 0.05)$ decrease in both absolute and relative weights of seminal vesicle, prostate and epididymis in all the treated animals when compared with the control. The epididymal acid and alkaline phosphatase contents and semen count decreased significantly $(\mathrm{p} \leq 0.05)$ in all the treated animals when compared with the control. The DNA and protein contents of seminal vesicle (SV), prostate (P) and epididymis (E) of albino rats treated with the B-success herbal supplement decreased significantly $(\mathrm{p} \leq 0.05)$ in all the treated animals when compared with the control. B-success herbal supplement may have toxic effect on the accessory sex organs of male albino rats.

(C) 2012 International Formulae Group. All rights reserved.
\end{abstract}

Keywords: B-success herbal supplement, seminal vesicle (SV), prostate (P) and epididymis (E), male albino rats.

\section{INTRODUCTION}

Male reproductive toxicology has recently become a rapidly extending area of research and testing. In the last decades, there has been growing concern over the effects of either synthetic or natural products on the male reproductive health (US EPA,
1996).Various plants like Vinca rosea, Solanum xanthocarpum, Bambusa amandinacea, Ocimum sanctum, Dolichos biflorus, Amaranathus spinosus, Carica papaya and Spirulina plantensis have been reported to possess antifertility activity (Murugavel et al., 1998; Rao, 1998; Chinoy et 
al., 1999). Treatment with such plants materials result in reducing the sperm count, motility, fertility, and viability, as well as increasing the amount of abnormal sperm. It has been suggested that the extract causes androgen depletion at the target level in the cauda epididymis, thereby affecting the physiological maturation of sperm (Chinoy et al., 1999). U and Dee Sweet bitter, a registered herbal supplement marketed in Nigeria has been reported to be toxic for the accessory sex organs of male albino rats (Obi and Orisakwe, 2011). Operation Sweep (OPS) de rheumatism powder, a registered Nigerian poly-herbal medicine has been reported to cause epididymal toxicity in male albino rats (Orisakwe et al., 2010). B-success herbal supplement has been reported to have testicular toxicity in male albino rats (Obi et al., 2011). Azadirachta indica has been reported to have anti-fertility, anti-spermatic activity, and a reversible anti-androgenic effect (Anjali et al., 1996).

The downturn in the Nigerian economy in the early eighties heightened the use of herbal remedies. Even the efforts made by the present government to provide a meaningful health care have not discouraged the people from seeing herbal medication as a popular choice. This resurgence of undying interest in herbal medication has prompted the National Agency Food Drug Administration Control (NAFDAC) to enforce a regulation of the manufacturing, sales and usage of herbal remedies in Nigeria. To this effect many of the herbal preparations available in the country have been registered in a bid to ensure standardization in labelling requirements, contents, precautions/contraindications, place of manufacture, date of manufacture, expiry date, etc. Again other preliminary investigations in our laboratory here in Nigeria have tended to suggest that some of these Nigerian traditional remedies possess testicular toxicity (Orisakwe et al., 2002, 2004b, 2004a).

Cases of reproductive failure after prolonged intake of herbal preparations have been anecdotally reported in Nigeria. An increasing number of cases remain undocumented due to poor record keeping as is obtained in the developing world (Orisakwe et al., 1996). Since these registered herbal remedies are widely used in Nigeria because of their acclaimed pharmacological properties, it is feared that high doses and chronic intake may be implicated in some undocumented cases of reproductive failure in men.

Nigeria has about 12 million infertile persons (Giwa-Osagie, 2003). Although there is a general documented belief that the most common cause of infertility in Nigeria is infection (Gates et al.,1995), cases abound where infection have been treated without correction of infertility (Giwa-Osagie,2003). In Nigeria there are higher rates of irreversible oligospermia or azoospermia than most other causes of infertility and less resources for the management of infertility (Osegbe and Amaka, 1985). Of all adult couples in African countries, it is estimated that $10-25 \%$ are subfertile and of these sub-fertile couples female factors account for about $55 \%$ and male factors for about $30-40 \%$ of causes, while 5$15 \%$ of causes are unexplained (GiwaOsagie,2003). It will be worthwhile investigating the possible toxicological implication and consequence of the heavy metals or any other adulterants/contaminants in these herbal remedies. B-success herbal supplement is a powdered herbal preparation registered and marketed in Nigeria with its acclaimed efficacy for treatment of infertility. The present study was undertaken to evaluate the effect of B-success herbal supplement on the accessory sex organs of male albino rats. 
MATERIALS AND METHODS

\section{Preparation of the extract of B-success herbal supplement}

Four hundred grams of the powdered B-success herbal supplement were macerated in one litre of ethanol for 24 hours. The solution was filtered and the filtrate was later concentrated with a vacuum evaporator Centre of Department of Pharmacognosy University of Nigeria, Nsukka, supplied the animals. The animals were fed ad libitum with standard rat chow from Pfizer Pharmaceuticals Plc, Ikeja, Nigeria. Water was also supplied along continuously.

\section{Subchronic toxicity study}

The lethal dose $\left(\mathrm{LD}_{50}\right)$ of the B-success herbal supplement has been determined to be $1260 \mathrm{mg} / \mathrm{kg}$. Twenty weight-matched male rats were shared into four groups of five rats each. The first group received $315 \mathrm{mg} / \mathrm{kg}$ ( $25 \%$ of the $\mathrm{LD}_{50}$ ), second group $630 \mathrm{mg} / \mathrm{kg}$ $\left(50 \%\right.$ of the $\mathrm{LD}_{50}$ ), and third group $945 \mathrm{mg} / \mathrm{kg}$ (75\% of $\mathrm{LD}_{50}$ ) of the B-success herbal supplement orally for 90 days. The control group received no herbal drug but had access to deionized water and were fed ad libitum with rat chow for 90 days. The feed and fluid consumption of the animals were measured on daily basis while their body weights were measured weekly.

\section{Preparation of animals for sacrifice}

At the end of the study period (90 days), the animals were anaesthetized with chloroform (Fission \& Scientific England) in absorbent cotton wool (Eao Pharmaceuticals, Benin City, Nigeria) and kept in a desiccator (Mermort Instruments, Germany) to prevent evaporation. Each animal was in turn put into the desiccator and the lid firmly put in place. The animals were later sacrificed; the prostrate, seminal vesicles and epididymis
(Model 249/2, Corning Ltd, England) for 8 hours.

\section{Animals study}

Adult male albino rats (165-250 g) and Swiss albino mice (18-35 g) of both sexes were used for the study. The Animal Facility

were harvested and their weights were measured. Epididymal sperm count was determined by the WHO Laboratory protocol (1992). The prostrate, seminal vesicles, and epididymal tissues were used for determination of protein (Sandermann and Stromiger, 1972) and DNA content (Slim and Stanford, 1976). The epididymal tissues were also used for the determination of acid phosphatase and alkaline phosphatise (Kind and King, 1954).

\section{RESULTS}

Table 1 shows the absolute and relative weights of seminal vesicle $(\mathrm{SV})$, prostate $(\mathrm{P})$, and epididymis (EP) of albino rats treated with the extract of B-Success. The results shows significant $(\mathrm{P} \leq 0.05)$ decrease in both absolute and relative weights of seminal vesicle, prostate and epididymis in all the treated animals when compared with the control. Also epididymal (E) acid and alkaline phosphatase contents and semen count of treated groups (Table 2) decreased significantly $(\mathrm{p} \leq 0.05)$ in all the treated animals when compared with the control.

Table 3 shows that DNA and protein contents of seminal vesicle $(\mathrm{SV})$, prostate $(\mathrm{P})$ and epididymis (E) of treated groups decreased significantly $(\mathrm{p} \leq 0.05)$ in all the treated animals when compared with the control. 
Table 1: Absolute and relative weights of seminal vesicle (SV), prostate (P), epididymis $(\mathrm{E})$ and final body weight of albino rats treated with the extract of Bsuccess drug and the control.

\begin{tabular}{|c|c|c|c|c|c|c|c|}
\hline $\begin{array}{l}\text { Dose } \\
(\mathrm{mg} / \mathrm{kg})\end{array}$ & $\begin{array}{c}\text { Absolute weight } \\
\text { (SV) (g) }\end{array}$ & $\begin{array}{c}\text { Relative weight } \\
\text { (SV) }(\%)\end{array}$ & $\begin{array}{l}\text { Absolute weight } \\
\text { (P) (g) }\end{array}$ & $\begin{array}{l}\text { Relative weight } \\
\text { (P) }(\%)\end{array}$ & $\begin{array}{l}\text { Absolute weight } \\
\text { (E) (g) }\end{array}$ & $\begin{array}{c}\text { Relative weight } \\
\text { (E) }(\%)\end{array}$ & $\begin{array}{l}\text { Final body } \\
\text { weight (g) }\end{array}$ \\
\hline $0.00^{\mathrm{a}}$ & $1.52 \pm 0.44$ & $0.67 \pm 0.22$ & $0.88 \pm 0.19$ & $0.38 \pm 0.10$ & $0.98 \pm 0.13$ & $0.42 \pm 0.03$ & $231.56 \pm 9.36$ \\
\hline 315 & $0.66 \pm 0.11 *$ & $0.28 \pm 0.08 *$ & $0.50 \pm 0.10^{*}$ & $0.21 \pm 0.04 *$ & $0.48 \pm 0.08 *$ & $0.20 \pm 0.02 *$ & $245.80 \pm 13.47$ \\
\hline 630 & $0.52 \pm 0.13^{*}$ & $0.23 \pm 0.06^{*}$ & $0.50 \pm 0.07 *$ & $0.22 \pm 0.03^{*}$ & $0.44 \pm 0.05^{*}$ & $0.19 \pm 0.03^{*}$ & $231.78 \pm 3.57$ \\
\hline 945 & $0.50 \pm 0.44^{*}$ & $0.20 \pm 0.07 *$ & $0.38 \pm 0.08^{*}$ & $0.15 \pm 0.03 *$ & $0.28 \pm 0.04 *$ & $0.11 \pm 0.02 *$ & $256.66 \pm 11.66$ \\
\hline
\end{tabular}

Table 2: Epididymal (E) acid and alkaline phosphatase contents and semen count of albino rats treated with the extract of B-success.

\begin{tabular}{cccc}
\hline $\begin{array}{c}\text { Dose } \\
(\mathbf{m g} / \mathbf{k g})\end{array}$ & $\begin{array}{c}\text { Epididymal } \\
\text { semen count }\end{array}$ & $\begin{array}{c}\text { Acid phosphatase } \\
(\mathbf{I U} / \mathbf{L})\end{array}$ & $\begin{array}{c}\text { Alkaline } \\
\text { Phosphatase (iu/L) }\end{array}$ \\
\hline $0.00^{\mathrm{a}}$ & $131.22 \pm 4.3$ & $11.86 \pm 0.51$ & $39.70 \pm 1.23$ \\
315 & $111.43 \pm .43^{*}$ & $7.54 \pm 15^{*}$ & $30.84 \pm 2.27^{*}$ \\
630 & $51.32 \pm 5.47^{*}$ & $5.08 \pm 0.68^{*}$ & $27.38 \pm 1.86^{*}$ \\
945 & $29.85 \pm 1.75^{*}$ & $3.96 \pm 0.86^{*}$ & $21.62 \pm 2.09^{*}$ \\
\hline Values are expressed as mean \pm SEM for $\mathrm{n}=5 ;{ }^{*}$ Significantly different from control $\mathrm{p} \leq 0.05 ;$ \\
a = Deionized water
\end{tabular}


Table 3: DNA and protein contents of seminal vesicle (SV), prostate (P) and epididymis (E) of albino rats treated with the B-success herbal supplement.

\begin{tabular}{|c|c|c|c|c|c|c|}
\hline $\begin{array}{l}\text { Dose } \\
(\mathrm{mg} / \mathrm{kg})\end{array}$ & $\begin{array}{c}\text { DNA }(\mu \mathrm{g} / \mathrm{ml}) \\
(\mathrm{SV})\end{array}$ & $\begin{array}{c}\text { Protein } \\
\text { (mg/gm } \\
\text { tissue) } \\
(\mathrm{SV}) \\
\end{array}$ & $\begin{array}{l}\text { DNA }(\mu \mathrm{g} / \mathrm{gm} \\
\text { tissue) } \\
(\mathbf{P})\end{array}$ & $\begin{array}{c}\text { Protein } \\
\text { (mg/gm } \\
\text { tissue) } \\
(\mathbf{P}) \\
\end{array}$ & $\begin{array}{c}\text { DNA }(\mu \mathrm{g} / \mathrm{gm} \\
\text { tissue }) \\
(\mathbf{E})\end{array}$ & $\begin{array}{c}\text { Protein } \\
\text { (mg/gm } \\
\text { tissue) } \\
(E) \\
\end{array}$ \\
\hline $0.00^{\mathrm{a}}$ & $5.84 \pm 0.43$ & $6.60 \pm 0.16$ & $5.19 \pm 0.02$ & $9.34 \pm 0.56$ & $6.39 \pm 0.06$ & $6.78 \pm 0.08$ \\
\hline 315 & $4.69 \pm 0.02 *$ & $3.94 \pm 0.20^{*}$ & $3.11 \pm 0.08^{*}$ & $5.18 \pm 0.18 *$ & $4.19 \pm 0.12 *$ & $2.96 \pm 0.30 *$ \\
\hline 630 & $3.63 \pm 0.02 *$ & $3.46 \pm 0.09^{*}$ & $2.46 \pm 0.09^{*}$ & $4.20 \pm 0.19^{*}$ & $3.12 \pm 0.07^{*}$ & $2.54 \pm 0.17 *$ \\
\hline 945 & $3.08 \pm 0.03 *$ & $2.88 \pm 0.16^{*}$ & $2.05 \pm 0.03^{*}$ & $3.04 \pm 0.15^{*}$ & $2.76 \pm 0.23^{*}$ & $2.12 \pm 0.13^{*}$ \\
\hline
\end{tabular}

\section{DISCUSSION}

The herbal medicines are being used by up to $80 \%$ of the population in developing countries. Despite widespread use, few scientific studies have been undertaken to ascertain the safety and efficacy of traditional remedies. The present study was undertaken to evaluate the effect of B-success herbal supplement on the accessory sex organs of male albino rats.

There was significant decrease in both the absolute and relative weights of the prostate, epididymis, and seminal vesicle in all the animals treated with B-success. The toxic effects of plant extracts were analyzed by monitoring alterations in body and organ weight of animals. In the male reproductive system, weight loss of the gonads, epididymides and accessory sex organs are considered standard criteria for the characterization of toxic agents that may cause fertility problems in the treated subject (Mishra and Singh, 2009). It has also been reported that ethanolic extract of Tecoma strans, a herbal medicine reduced significantly the relative weight of testes, epididymis, vas deferens, prostate and seminal vesicle in male albino rats (Nidhi et al., 2010). Operation Sweep (OPS) de rheumatism powder, a registered Nigerian poly-herbal medicine, has been reported to cause a significant reduction of the relative weight of the epididymis in male albino rats
(Orisakwe et al., 2010). U and Dee Sweet bitter a registered herbal supplement marketed in Nigeria has also been reported to be toxic to the accessory sex organs of male albino rats (Obi and Orisakwe, 2011).

From previous study, the administration of B-success herbal supplement was found to cause a significant decrease in epididymal semen number (ESN) (Obi et al., 2011) and this decrease must have brought about a highly significant loss in accessory sex organ weights, which are known to be mostly related to the number of spermatids and spermatozoa in the tissue. The decreasing weight of the reproductive organs in the extract-treated male rats clearly indicated that the extract caused structural and functional alteration in the testes, epididymis, seminal vesicle, ventral prostate and vas deferens (Sarkar et al., 2000). Reduction in the weight of accessory sex organs might be due to low level of androgen, which was not enough to maintain the weight of gonads and accessories ( Singh and Singh, 2009). Operation Sweep (OPS) de rheumatism powder has also been reported to cause epididymal toxicity in male albino rats ( Orisakwe et al.,2010).

This study revealed that there was significant decrease $(\mathrm{P}<0.05)$ in epididymal acid phosphatase (ACP) and epididymal alkaline phosphatase (ALP) levels in all the animals treated with the aqueous extracts of 
B-success. The epididymides are known to provide a suitable environment for morphological and biochemical changes in spermatozoa (Manonayagi et al., 1987). Acid phosphatase and alkaline phosphatase serve as reliable markers for androgen action in the accessory organs of male animals and their levels are directly correlated with sperm counts (Orgebin-Crist, 1996). The observed reduction in the activities of these enzymes and reduction in ESN by these herbal remedies suggest a decreased androgen supply to the epididymides. This is in agreement with the work of Manonayagi et al., 1989 that reported reduction in epididymal ACP and ALP by the ethanolic extract of Bambusa arundinaceae. Amalakyadi churna, has also been reported to cause reduction in the activity of ACP in male albino mice (Setharam et al., 2003). The seed extract of Carica papaya another common plant also caused reduction in the epididymal ACP in male albino rats (Verma and Chinoy, 2001). U and Dee Sweet bitter, a registered herbal supplement in Nigeria, has been reported to decrease the epididymal ACP and ALP in male albino rats (Obi and Orisakwe, 2011). Similarly B-success also significantly decreased $(\mathrm{p}<0.05)$ the DNA and protein contents of the accessory sex organs which have been found to be decreased by the aforementioned herbal remedies. $U$ and Dee Sweet bitter has been reported to decrease the DNA and protein contents of the accessory sex organs of male albino rats (Obi and Orisakwe, 2011).

A major strength in conducting sperm evaluations in test animals is that similar data can be obtained from humans, enhancing the ability to confirm effects seen in test species and vice versa (Zenick and Clegg, 1989). Standard toxicity studies that are limited to fertility evaluations provide insufficient information to conclude that synthetic or natural product possesses no reproductive hazards to humans (Dalsenter et al., 1997). Unlike humans, normal males of most animal models produce sperm in numbers that greatly exceed the minimum requirements for fertility. In some strains of rats and mice, sperm production can be reduced by $90 \%$ without compromising fertility. However, less severe reductions can have dramatic consequences for human males who are close to the threshold for the number of sperm needed to ensure reproductive competence (Toppari et al., 1996). This situation reinforces the importance of determining possible adverse effects of either synthetic or natural products on the male reproductive system as a part of safety evaluation.

The human males have a relatively low sperm count; the number of sperm per ejaculate is typically only 2- and 4- fold higher than that at which fertility is significantly impaired. In contrast the number of sperm in a rat or rabbit ejaculate is many times (up to 1000-fold) that which will produce maximum fertility. The epididymal sperm count can be reduced by as much as $90 \%$ in the rat without significantly affecting fertility. Thus, a reduction in sperm concentration that did not alter rat fertility might have an important effect on human fertility.

\section{Conclusion}

B-success herbal supplement may have toxic effect on the accessory sex organs of male albino rats. This study forms a basis for studies in man, and involving yet lower concentrations, to determine at what concentrations B-success may be said to be non-toxic to the accessory sex organs. Further studies are necessary to clarify the mechanisms of the various phytoconstituents found in herbal supplements and to study their effects on the reproductive/ endocrine function and on various hormone parameters.

\section{REFERENCES}

Anjali RJ, SNazeer Ahmed R, Pathan KM, Manivannan B. 1996. Effect of Azadirachta indica leaves on testis and its recovery in albino rats. Indian J. Exp. Biol., 34: 1091-1094.

Cates W, Farley TMM, Rowe PJ. 1985. World wide patterns of infertility. Is Africa different? Lancet, 2: 596-298.

Chinoy NJ. 1999. Geeta Ranga 
Antiandrogenic and antifertility effects of Vinca ro leaf extract in male albino rats. Comp. Physiol. Ecol., 8: 41-51.

Dalsenter PR, Fagui AS, Webb J, Merker HJ, Chahoud I. 1997. Reproductive toxicity and toxicokinetics of Lindane in the male offsprings of rat exposed during lactation. Hum. Experimental Toxicol., 16: $146-153$.

Giwa-Osagie OO. 2003. Nigeria has twelve million infertile persons. Pharmanews, 25(7): 48-49.

Kantak NM, Gogate M. 1992. Effect of short term administration of Ocimum sanctum Linn on reproductive behaviour of adult male rats. Indian. J. Physiol Pharmacol., 36: 106-111.

Kind PRN, King EJ. 1954. Estimation of plasma phosphatase by determination of hydrolysed phenol with aminoantipyrine. J. Clin. Path., 7(4): 322-326.

Manonayagi S, Vanithakumari G, Padma S, Malini T. 1987. Effects of bamboo budsistructural and functional changes in the epididymis of rats. J. Ethnopharm., 25: 201-212.

Mayorga L, Bertini F. 1981. Acid hydrolases in the epididymis of normal castrated, vasectomised, cryptorchid and cryptoepididymal rats. Int. J. Androl., 4: 208-219.

Mishra RK, Singh SK. 2009. Antispermatogenic and antifertility effects of fruits of Piper nigrum L. in mice. Indian J. Exp. Biol., 47: 706-712

Murugavel T, Ruknudin A, Thangravelu S, Akbarshar MA. 1998. Artifertility effect of Vinca rosea (Linn) leaf extract in male mice- A Sperm parametric study. Curr. Sci., 58: 1102-1103.

Murugan K, Vanithakumari G, Sampathraj R. 1993.Effect of combined extracts of Dolichos biflorus seeds and Amaranthus spinosus roots on the accessory sex organs of male rats. Ancient. Sci. Life, 12: 351-357.

Nidhi M, Jain GC, Pandey G. 2010. Effect of Tecoma Stans leaves on the Reproductive System of male Albino rats. Int. J. Pharmc., 6(2): 152-156.

Obi E, Orisakwe OE. 2011. Effect of SubChronic Adminstration of $U$ and Dee Sweet Bitter Herbal Supplement on the Accessory Sex Organs of Male Wistar Rats. World Appl. Sci. J., 15(7): 973977.

Obi E, Afonne OJ, Orisakwe OE. 2011. Testicular toxicity of B -success herbal supplement in male albino rats. Int. Research Pharm. Pharmac., 1(8) : 221227.

Orgebin-Crist, MC. 1969. Studies on the function of the epididymis. Biol. Of Reproduction, 1: 155-175.

Orisakwe OE, Afonne OJ, Dioka EC, Agbasi PU, Azikiwe C, Obi E. 2002. Testicular Toxicity of Rinbacin in Rats. Biol. Pharm. Bul., 25(2): 206-208.

Orisakwe OE, Akumka DD, Njan AA, Afonne OJ. 2004a. Testicular Toxicity of Nigerian bonny light crude oil in male albino rats. Repro. Toxicol., 18: 439442.

Orisakwe OE, Debem HC, Etuk EU, Elsa AT. 2010. Spermatoxic effects of operation sweep herbal supplement in male albino rats. J. Basic Clin. Physiol. Pharmac., 21(2): 147-156.

Orisakwe OE, Dioka CE, Ofoefule SI. 1996. A comparative review of poisoning in Nigeria. J. W. Afr. Pharm., 10(2): 53-55.

Orisakwe OE, Husaini DC, Afonne OJ. 2004b. Testicular effects of sub-chronic administration of Hibiscus sabdariffa caylx aqueous extract in rats. Reprod. Toxicol., 18: 295-298.

Osegbe DN, Amaka EO. 1985. The cause of male infertility in 504 consecutive Nigerian patients. Int. Urol. Nephrol., 17: 349.

Rao MV. 1998. Effect of alcoholic extract of Solanum xanthocarpum seeds in adult male rats. Indian J. Exp Biol., 26: 95-98.

Sandermann, Stromiger. 1972. Protein Assay, J. Biol Chem., 247: 5123-5131.

Sarkar M, Gangopadhyay P, Basak B, Chakrabarty K, Banerji J, Adhikary P, 
Chatterjee A, 2000. The reversible antifertility effect of Piper beetle Linn. on Swiss albino male mice. Contraception., 62: 271-274.

Sharma A, Mathur A, Mathur R, Sharma S, Dixit VP. 1994. A novel male antifertility agent; Spirulina plantensis (Blue green algae). Natl. Symp. Repod. Health Care and V Ann. Meet. Indian Soc. for the Study of Reprod. Fertil. Abs.68.

Shaikh PD, Manivannan B. 1993. Antispermatic activity of Azadirachta indica leaves in albino rat. Curr sci., 64: 688.

Singh A, Singh SK. 2009. Evaluation of antifertility potential of Brahmi in male mouse. Contraception., 79: 71-79. Slim and Stanford.1976. DNA Isolation from Tissues and cell lines, Modification of Slim and Stafford. Nucl. Acids Res. 3: 2303.

Toppari J, Larsen CL, Christiansen P, 1996. Male reproductive health xenoestrogens. Environ Health Perspect. , 104: 741803.

US EPA (US Environmental Protection Agency). 1996. Guidelines for reproductive toxicity risk assessment. [EPA/630/R-96/009]. http://cfpub.epa. gov/ncea/cfm/recordisplay.cfm?deid=28 38

Vanithakumari G. 1989. Antifertility effect of Bambusa arundinacea shoot extracts in male rats. J. Ethnopharmacol., 25: $173-180$.

Verma RJ, Chinoy NJ. 2001. Effect of Carica papaya seed extract on microenvironment of cauda epididymis. Asian J. Androl., 3(2): 143-146.

Vijaykumar MB, Patil SB. 2003. Antifertility effect of ethanolic extract of Amalakyadi Churna in male albino rats. Asian. J. Androl., 5(3): 247-250.

World Health Organization WHO. 1972. Laboratory Manual for Examination of Human Semen and Semen-Cervical Mucus Interaction. Cambridge University Press: Cambridge, U.K.; 255258.

Zenick H, Clegg ED. 1989. Assessment of male reproductive toxicity. A risk assessment approach. In Principles and Methods of Toxicology, Hayes W (ed). Raven Press: New York; 275-309. 